\title{
Talent Mobility Program: Diagnostic Process and Facilitating Systemic Change at the Telkom Group
}

\author{
Soraya Agustina Situmorang ${ }^{1}$, Lelo Yosep Laurentius ${ }^{2}$, Hendry Hartono ${ }^{3}$ \\ 1,2,3 Manajement Department, BINUS Business School Undergraduate Program, \\ Bina Nusantara University, \\ Jakarta 11480, Indonesia \\ soraya.situmorang@binus.ac.id; lelojose@binus.ac.id; hhartono@binus.edu
}

\begin{abstract}
This study aims to understand that the talent mobility program in the Telkom group is a strategy, process and practice of human resources. This qualitative study evaluates the talent mobility program with the 2017-2019 CIPP (Context, Input, Process, Product) model in the Telkom Group. Data were collected through document studies, observations, questionnaires, FGDs from former program participants, program participants, and indepth interviews with Telkom Group Human Capital Management Director, TELKOMSEL Vice President People Development, Telkom Indonesia International Finance \& Human Capital Director, and Chair of the Trade Unions Telkom Group. Analysis and interpretation of data shows that (1) the program contributes to assessing the effects of the human resource strategy on the Telkom Group's business strategy; (2) The program has dynamic planning and human resource control so that it is integrated with the business strategy and critical position in the Telkom Group; (3) The program is a method of accounting for human resources, namely the calculation of investments made to recruit, evaluate and train the potential of top talent to create a sustainable competitive advantage of the Telkom Group; and (4) The talent pool system in the program serves to accommodate the recognition of the needs, goals, and achievements of the top talent in the Telkom Group. The findings lead to a recommendation that the long-term organization availability of the Telkom Group depends on this talent mobility program. This is because the talent mobility program is a diagnostic process and facilitates systemic change in the Telkom Group through human capital.
\end{abstract}

Keywords - Talent, Mobility Program; Systemic Change.

\section{INTRODUCTION}

The Indonesian Product Development and Management Association (PDMA), PPM Management and SWA Media Group named PT Telkom Indonesia Tbk as Indonesia Most Creative Companies 2019. PT Telkom Indonesia Tbk has three main aspects to reach the top rank as the Indonesia Most Creative Companies 2019, namely product aspects as well as services and business strategies, original and different company innovations and good company performance as evidence of the innovation and creativity that the company has carried out. Talent mobility programs contribute greatly to these three main aspects. He designed the use of the attitudes, skills, and knowledge of top talents in all subsidiary organizations of the Telkom Group (Evanisa et al., 2015). Telkom Group's Human Capital Management has launched a talent mobility program into a strategy to create synergy across units and across departments through top talent from within the Telkom Group.

The systematic management of talent mobility in organizations, according to Navaz, has five strategic objectives (Newhall, 2012). First, management analyzes and designs leadership development and leadership skills from within the organization. Second, management retains top talent, who have critical skills, through opportunities and global career development to maintain their performance in the organization. Third, management makes the development of knowledge and transfer knowledge in a global work environment. Fourth, management attracts top talent and those who have critical skills to optimize the efficiency and effectiveness of the organization's 
operations. Fifth, management ensures that the right talent is in the right place at the right time to maintain the competitive power of the organization.

The talent mobility program was originally designed as a distribution system for top talent across units and departments from and for the Telkom Group. However, the Telkom Group still has gaps in flexibility, productivity and profitability between units, departments and its subsidiaries, due to the large ratio of differences between the number of program participants and the total number of employees. Until 2019 the number of program participants has not reached 100 people, while the total number of Telkom Group employees is up to 25,000.

One of the most important results of this study, the talent mobility program launched in 2015 , significantly diagnosed and eased the systemic changes in the Telkom Group in 2017-2019. The program improves the ability of the Telkom Group organization to compete in a number of countries worldwide in the technology and communications industry. Therefore, this study aims at how the talent mobility program as a personnel strategy, which is integrated in the planning and control of the business plan strategy of the Telkom Group, can also be implemented in the management of top talents in state-owned companies (BUMN), regional companies (BUMD), all Indonesian ministries and all local governments in Indonesia. Why? In the time of the service economy, the potential of strategic personnel services becomes a sustainable competitive advantage. Other sources such as finance and suitable technologies are proven to be able to move quickly and are not tied to culture. They can be transferred, sold and moved across company and state borders. The adaptation and effective use of new technologies by competitors is so fast that the advantages of the technology can be weakened without personnel skills. Therefore, respect for strategic human resources is becoming increasingly important for all organizations that want to remain competitive.

\section{METHODS}

This study uses a qualitative approach to assess talent mobility programs in the Telkom group. Determination of the respondents for interviews that are deliberately conducted according to the criteria of managers and program participants, former program participants and focus group discussions (FGD). Primary data acquisition using observation, interview and questionnaire techniques. While secondary data in the form of all participant information on the program. The researchers also visited the Telkom Group's headquarters, the TELKOMSEL headquarters, the Telkom Group's workers' union, and the international telecommunications center in Indonesia to make observations. The data obtained is analyzed using a descriptive analysis of the CIPP component (Context, Input, Process, Product) using data reduction techniques, data presentation and drawing / review conclusions.

\section{RESULT AND DISCUSSION}

Humans are the key to the success of all organizations. The competitiveness of human resources at the international level is the basis for the legality of the talent mobility program in the Telkom group (Evanisa et al., 2015). From a business perspective, the Telkom Group is a complex company, although its core business is communication technology. Therefore, he must have an innovative program to meet the diversity of individual needs, especially the top talents. Talent mobility programs require organizational systems such as management, planning and control that can take into account the dynamics of the global diversity of the workforce in terms of gender, lifestyle, age and ethnic background (Cheese et al., 2007). The program is therefore an innovation from the perspective of strategy, regulation and implementation of talent management (Dessler et al., 2005).

According to Vladi, talent management is an important process in organizations in the form of recruiting, evaluating and maintaining top talent so that they are always tied to the company's business strategy (Posumah, 2013). High learning ability, adaptability to change and the ability to tolerate darkness are a number of standard attitudes of top talents. Because participants will experience more cross-training that focuses on relationships with other people and the development of strategic leadership management.

Participants must be recruited from various Telkom Group subsidiaries. This is because this program is both a driver and a parameter for Telkom Group's organizational strategy to interact with various competing organizations worldwide. Externally, this interaction requires a variety of Telkom Group's human capital 
management achievements. Internally, this interaction supports the knowledge management system to support the organizational change and development initiatives of the Telkom Group. Top talents are therefore always different knowledge and skills about different international business systems. Here, top talents are the main actors to find various creative strategies to maintain the performance of the Telkom group.

The Telkom Group's Human Capital Management also recognizes that talent mobility programs require organizational responsibility to ensure the careers of top talent and maintain the company's competitive advantage. The top talent mobility program was therefore implemented in all units, departments and subsidiaries of the Telkom Group. The program has therefore strengthened management positions and at the same time enabled succession planning throughout the company. The program has also created organizational development through synchronization and synergy of human capital strategies, policies and practices as the Telkom Group's business strategy. Synchronization and synergy can be found in the talent pool, which offers a tracking and development path for the mobility of top talents and executives in the Telkom Group.

With this program, the Telkom Group is the first state-owned company (BUMN) in Indonesia to have a method of accounting for its human resources. Why? The system calculates investments for recruiting, evaluating and training top talents, which at the same time diagnose and facilitate systemic changes in the Telkom group. This is of course related to the economic transition. The transition from industry to an economy based on knowledge and information. The sustainability of the competitive advantage of knowledge and information-based organizations requires the development of methods for calculating investments in people's skills.

The talent mobility program is an innovative talent management process, which is a holistic, integrated and goal-oriented planning, recruitment, selection, development and remuneration process for employees (Rexhepi et al., 2015). The performance of the program flows is shown in the flow chart in Figure 1, so that a system for analyzing the training needs is in place that imparts knowledge and skills to potential managers in the Telkom group. The program evaluates what skills are needed and what skills are available. The program regulates the suitability of the skills of top talents for global competition. As a result, this program has comprehensive and consistent policies and practices in the areas of talent selection, performance appraisal, compensation, training and development, positive action and relationships with Telkom Group's business strategies.

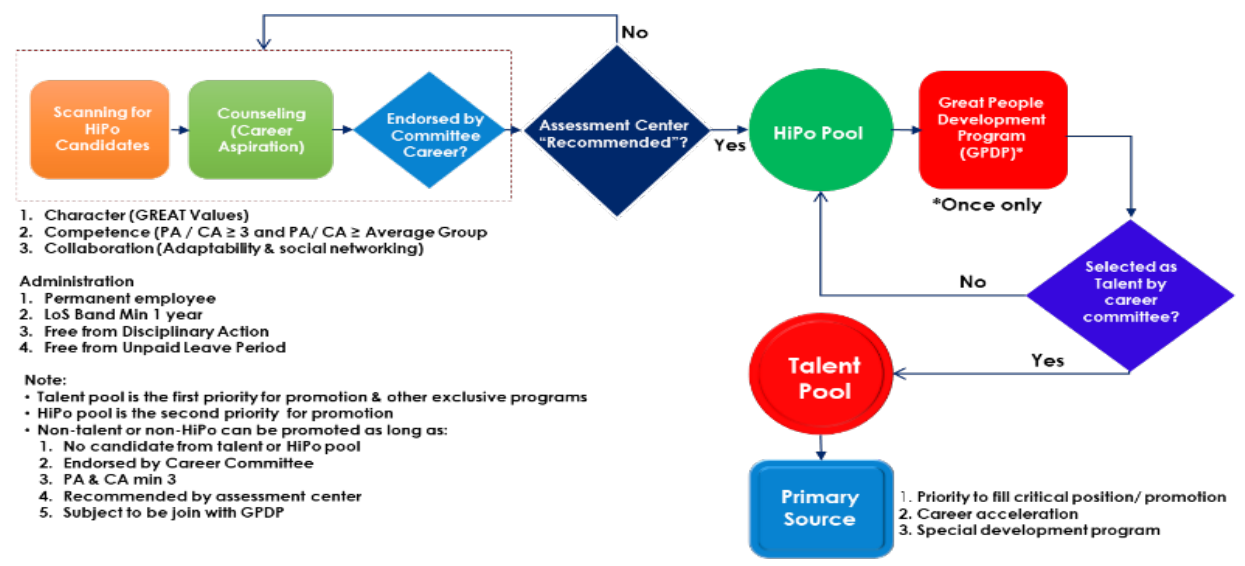

Figure 1 Flow Diagram of the Talent Mobility Program at the Telkom Group (Source: Adaptation from the Decree of the Director of the HCM Telkom Group)

How does the flowchart work in the Telkom group? Each CHCO (Chief Human Capital Officer) determines who is the top talent by performing an appropriate test for the candidates participating in the program. The phases of fit and proper testing consist of: (a) grouping top talents; (B) setting criteria for the evaluation of top talents; (c) determining the top talent participants; (d) recommendations and plans for developing top talent; $\mathrm{e}$ ) the period of validity of the top talent group program; (f) plan to implement top talent; (g) professional development requirements for top talent; (h) types of mobility of top talent; (i) preparing the module to develop top talent mobility; (j) preparing modules for the transfer of top talent mobility; (k) preparing top talent transfer modules; (1) preparation of suitable and suitable test instructions; (m) provisions on the compensation of movements before and after joining the program; and (n) preparing the rights and obligations of the original organization and the target organization. In short, the flowchart contains settings, selection and training. Recruitment is the search for top talents who are actively needed for the program. The selection is the right choice among top talent applicants to fill critical positions in the Telkom Group. The training imparts the skills and knowledge that the top talent 
needs to do critical work effectively.

This flowchart becomes an initiative for a successor strategy map. It is useful to summarize how the performance of each department and unit contributes to achieving the overall strategic goals of the Telkom Group through strategic tools for personnel management. The Career Committee, which has cross-sector management experience, selects the ethical competence requirements of top talents for critical positions in the Telkom Group. Critical positions are strategic positions that guarantee the Telkom Group's competitive advantage in an international environment (Nawaz, 2013).

Ethical competencies consist of a) $50 \%$ of the characters, namely integrity, enthusiasm and wholeness; b) $30 \%$ competence, d. H. individual skills, knowledge and quality. and c) $20 \%$ collaboration, namely teamwork, teamwork + partnership development and teamwork + partnership development + networking. The results show that the Careers Committee implemented the 2019 program more efficiently and effectively than in 2018 . Surveys and opinions from participants $54.50 \%$ of those surveyed agreed that the Careers Committee introduced good governance in 2018 to attract top talent, but $45,50 \%$ doubted this. The results of the participant interviews and the opinions of 58.40 respondents agreed that the Career Committee introduced good governance in 2019 to attract top talent, but 41.60 doubted this. The focus group discussion (FGD) raised doubts about the capabilities of the talent mobility system and procedures, as $\mathrm{CHCO}$ did not conduct regular socialization to recruit top talent.

Talent mobility program planning involves determining needs, setting goals, and carefully outlining procedures. Planning is intended to achieve the goals of the talent mobility program as well as to provide clear job descriptions that determine the tasks and requirements of the top talents in their respective organizations. Meanwhile, control requires the use of various methods by the Career Committee to boost the performance of all Telkom Group subsidiaries through the talent mobility program planning scheme. At least, there are two control factors that require attention, namely organizational structure and supervision.

Talent mobility is a complex program. Their implementation requires a systematic approach. The approach aims to overcome a number of challenges and obstacles to talent mobility within the Telkom group. The challenges of talent mobility, according to Mullaney, are:1) Aligning current and future talent needs to rapidly changing business needs; 2) Developing deep talent succession pools and bench strength; 3) Retaining high performers and potentials/reducing flight; 4) Reducing external recruiting costs; and 5) Improving overall HR measurement and reporting (James, 2012). Meanwhile, according to Mullaney, the obstacles are: 1) There is no single, complete display of global talent because of the integration of processes, systems and data; 2) No succession planning process, or no focused only on senior execs; 3 ) Inconsistent employee assessment process and inability to calibrate ratings; 4) Sporadic, unpersonalized and informal employee development process (James, 2012). In order to overcome these challenges and obstacles, the career committee has the privilege to implement a talent mobility program (Nawaz, 2013). The privilege relates to the main responsibility of the career committee to prepare top talents for filling various critical positions in the Telkom group (Nawaz, 2013). The career committee includes all CHCO companies (Chief Human Capital Officer) of the Telkom Group, as shown in Figure 2.

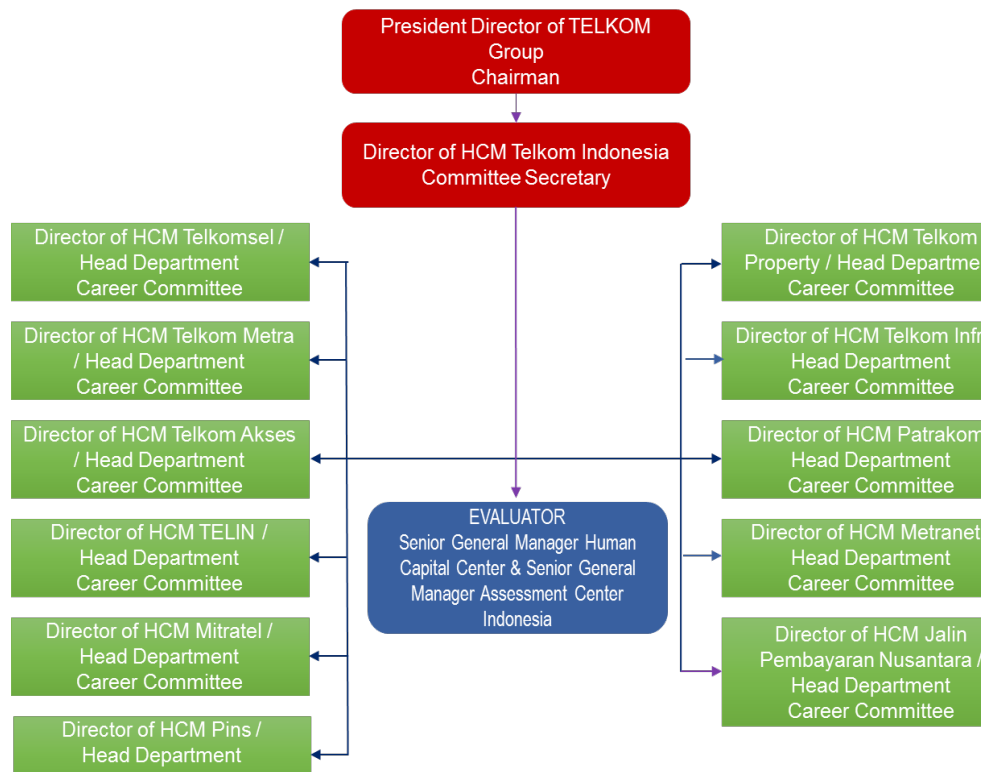

Figure 2 The Organizational Structure of the Career Committee (Source: Adaptation from the Decree of the Director of the HCM Telkom Group) 
The program's control and supervision functions are shown in Figure 2, which aims to ensure the development of human resources through talent mobility are in line with the Telkom Group's strategy. The talent mobility program is carried out by three methods: a) Transfer: the host gets permanently superior resources; $b$ ) Development: home obtains media for the development of its employees through job enrichment and enlargement at the Telkom Group; c) Skill Transfer: home gets the media for the development of its employees through job enrichment and enlargement, and the host gets additional resources needed in working on the project.

The talent mobility program through these three methods aims to implement a new training and communication program, which aims to ensure all top talents understand the importance of international business strategies, and what all prospective leaders in the Telkom Group need in terms of service, opportunity utilization, and high-quality service offerings to stakeholders and shareholders. These three methods are also intended to accommodate cross-cultural knowledge management so that the Telkom Group becomes an international learning organization (Evanisa et al., 2015). Therefore, sharing knowledge about the international business experience is a mandatory activity for all program participants so that tacit knowledge from top talent is transformed into explicit knowledge for the Telkom Group corporation.

The findings of the interviews and the results of $77.30 \%$ of respondents agreed that the method of talent mobility program activities responded to the dynamics of global business challenges, namely high-performance work systems, but $22.70 \%$ doubted it. Then, the Focus Group Discussion (FGD) concluded that there was a positive contribution from the Career Commission's prerogative to choose participants. The diversity of competencies in managerial experience in the Career Commission ensures the management of cross-sector knowledge management in talent mobility programs.

The results of the interviews and Focus Group Discussion (FGD) found other findings on the talent mobility program, namely that more top talent employees cannot manage their careers in the Telkom Group after undergoing a two-year program. The problem lies in the procedures and mechanisms of control and supervision at the host. The participants did not get regular reports about their performance while being hosted. That is, the top talent does not know the map and the direction of his career during the program at the host. As a result, they did not actively participate in adjusting their behavior and competencies to meet the needs of the Telkom Group's business strategy. This is consistent with the opinions of $68.20 \%$ of respondents who doubted their career continuity internationally at the Telkom Group, but $31.80 \%$ agreed.

Then, another finding from the interviews and Focus Group Discussion (FGD) was that program participants created various functional strategies, namely strategies that identified what each department and each unit had to do for business development related to Telkom Group's strategic objectives. This is in accordance with the opinion of $68.10 \%$ of respondents who agree that the talent mobility program opens broad opportunities to innovate, but $31.80 \%$ doubt it. A talent management strategy through a talent mobility program aims to "the right person, in the right place, at the right time at the right time at the right cost". This is consistent with Kehinde's opinion on talent management is an effort to implement an integrated system in order to improve the production process by developing, maintaining, and utilizing the attitudes, skills, and knowledge of top talent in accordance with the dynamics of current and future business needs (Ingham, 2007). So, talent mobility programs are a global and international career design for top talent through the Telkom Group. This program creates opportunities for top talent to expand their competencies.

Meanwhile, Collings and Mellahi argue that strategic talent management is a process strategy to systematically identify a number of different key positions in order to boost sustainable competitive advantage through the development of high-performing organizations for top talent to fill these key positions (Collings et al., 2009). Then, Collings and Mellahi emphasized that strategic talent management aims at developing an architecture of human resources that facilitates the success of strategic positions from within the organization while ensuring the ongoing commitment of top talent to the organization (Collings et al., 2009). In developing to improve productivity and the various types of benefits that will be generated, capital and technology are important weapons. However, only humans can determine who wins. 


\section{CONCLUSION}

The Telkom Group talent mobility program is an innovative process of managing strategic human resources to maintain its competitive edge. The Telkom Group shows other organizations without programs, regulations, and resources, strategic human resource management will not be effective. Therefore, to lead human resource programs, special skills are needed to make the design, development, implementation, and maintenance of programs or management tools that are needed. Therefore, human resources are very important for health and organizational stability in the long run.

\section{REFERENCES}

Cheese, P., Thomas, R. J., \& Craig, E. (2007). The talent powered organization: Strategies for globalization, talent management and high performance. Kogan Page Publishers.

Collings, D. G., \& Mellahi, K. (2009). Strategic talent management: A review and research agenda. Human resource management review, 19(4), 304-313.

Dessler, G., \& Varrkey, B. (2005). Human Resource Management, 15e. Pearson Education India.

Evanisa, F. W., \& Susanty, A. I. (2015). Pengaruh Individu, Organisasi, Dan Teknologi Terhadap Knowledge Sharing Di Direktorat Human Capital Management Kantor Pusat Pt Telekomunikasi Indonesia, Tbk. eProceedings of Management, 2(2).

Ingham, J. (2007). Strategic human capital management. Routledge.

James Sunday Kehinde PhD, A. C. A. (2012). Talent management: Effect on organizational performance. Journal of management research, 4(2), 178.

Newhall, S. (2012). A global approach to talent management. Human Resource Management International Digest.

Nawaz, N. (2013). Impact of talent mobility on employee performance in software companies, Bangalore. The International Journal of Management, 2(1).

Posumah, P. I. C. (2013). Evaluasi Penerapan Pemungutan Pajak Pertambahan Nilai (PPN) Pada PT Telekomunikasi Indonesia Tbk Manado. Jurnal EMBA: Jurnal Riset Ekonomi, Manajemen, Bisnis dan Akuntansi, $1(3)$.

Rexhepi, I., \& Vladi, B. (2015). Talent Management and Organizational Quality Improvement. Academic Journal of Interdisciplinary Studies, 4(3), 157-157. 